\title{
Differentiated all-trans retinoic acid response of naive CD4+CD25- cells isolated from rats with collagen-induced arthritis and healthy ones under in vitro conditions
}

\author{
ISAURA FELCENLOBEN ${ }^{1}$, EDYTA ŻYROMSKA ${ }^{1}$, TOMASZ PIASECKI ${ }^{2}$, JOANNA ROSSOWSKA ${ }^{3}$, \\ ANNA KĘDZIERSKA ${ }^{3}$, MARCIN NOWAK ${ }^{4}$, MARCIN ŻYROMSKI ${ }^{5}$, ANNA CHEŁMOŃSKA-SOYTA ${ }^{1,3}$

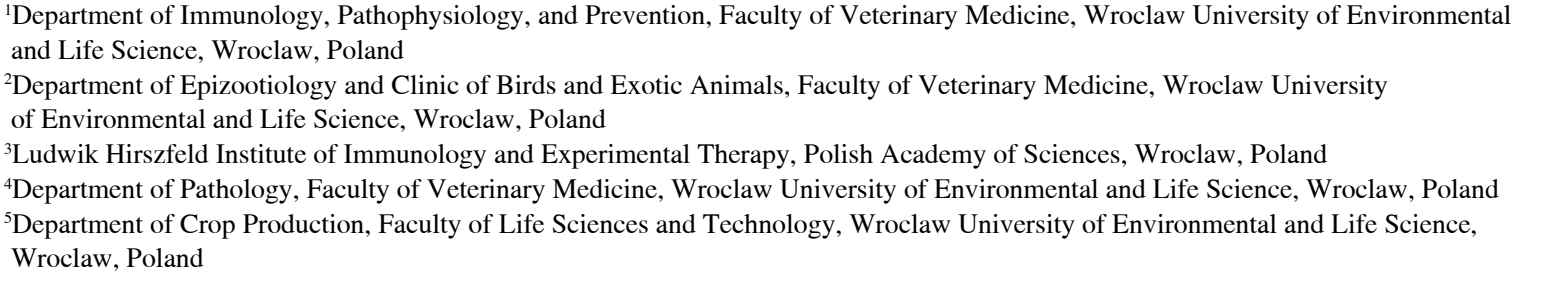

\begin{abstract}
Aim o the study: To compare the potential of CD4+CD25-cells, isolated from both healthy rats and rats with CIA (Collagen-Induced Arthritis), for differentiation into regulatory $T$ cells in the presence of all-trans retinoic acid in order to learn more about the activation mechanisms and therapeutic potential of regulatory $T$ cells.

Material and methods: Sorted CD4+CD25-cells were cultured in vitro with/without ATRA, and then the frequency of regulatory $T$ cells and their ability to secrete IL-10 by CD4+FOXP3+ cells was examined. Gene expression of the foxp $3, \operatorname{rar} \alpha, \operatorname{rar} \beta, \operatorname{rxr} \beta$, and ppar $\beta / \delta$ and protein expression of the Rar $\alpha$, Rar $\beta$, and Rxr $\beta$ in cells after stimulation with ATRA were also investigated.

Results: $C D 4+C D 25$ - cells isolated from healthy animals or from animals with CIA are characterised by different potential of the differentiation into CD4+CD25+FOXP3+ cells. Retinoic acid receptor Rxr $\beta$ is present in the $C D 4+C D 25$ - cells isolated from rats with CIA.

Conclusions: We showed that although ATRA did not increase the frequency of Treg in culture, it significantly increased expression of rar $\beta$ and rxr $\beta$ only in lymphocytes taken from diseased animals and foxp3 expression only in healthy animals. Moreover, after ATRA stimulation, the frequency of Treg-produced IL-10 tended to be lower in diseased animals than in the healthy group. The results imply that the potential of nadve cell CD4 lymphocytes to differentiate into Tregs and their putative suppressive function is dependent on the donor's health status.
\end{abstract}

Key words: regulatory T cells, Treg, all-retinoic acid, atra, collagen-induced arthritis.

(Cent Eur J Immunol 2016; 41 (4): 39-53)

\section{Introduction}

Among the regulatory $\mathrm{T}$ lymphocytes (Treg) characterised by the CD4+CD25+FOXP3+ phenotype, three basic subpopulations are distinguished based on the place of their development. First, the thymus regulatory $\mathrm{T}$ cells (tTregs or nTregs), which are developed in the thymus. Second, the peripheral regulatory T cells (pTregs) produced peripherally in the spleen and lymph nodes, and gut-associated lymphoid tissue (GALT) from naive
CD4+CD25- lymphocytes as a response to antigen stimulation; and third, the iTregs - cells induced under in vitro conditions [1].

The Treg lymphocytes are responsible for peripheral tolerance of self-antigens, and they control the immune response process against exogenous antigens [2]. Their immunosuppressive effect is conditioned by stable expression of the FOXP3 transcription factor and consists - among others - of the release of immunosuppressive cytokines such as IL-10 and TGF- $\beta$, as well as the reduction of an-

Correspondence: Isaura Felcenloben, Department of Immunology, Pathophysiology, and Prevention, Faculty of Veterinary Medicine, Wroclaw University of Environmental and Life Science, Norwida 31, 50-375 Wroclaw, Poland, e-mail: isaura.felcenloben@ gmail.com Submitted: 31.12.2015; Accepted: 28.05.2016 
tigen presentation by antigen-presenting cells, by blocking their costimulatory function [3]. Some Tregs can be differentiated from CD4+ in the presence of IL-10 in in vitro conditions. These Tregs have been named Treg 1, and their main characteristic feature is high secretion of IL-10. However, it is also possible to obtain in vitro Tregs that produce TGF- $\beta$ (named Th3) [4].

Maynard's team demonstrated that, despite the induction of Foxp3 by TGF- $\beta$, ATRA in vitro in the signal path of TGF- $\beta$ inhibits the secretion of IL-10 in CD4+ naive cells. Similarly, in vivo ATRA produced in the small intestine by dendritic cells inhibits induction of IL-10 in CD4+ cells but initiates the expression of Foxp3. In their studies, they also made the control cell cultures of CD4+ T cells in the presence of a RAR antagonist - LE540, which resulted in secretion of IL-10 at a level significantly higher than in culture only with TGF- $\beta$ or TGF- $\beta$ + ATRA. Same team also demonstrated that ATRA inhibits only transcription, but not translation of IL-10 [7]. However, supplementation of diet with high dose of ATRA in Balb/c mice has significantly increased secretion of IL-10 in lymphocytes isolated from lymph nodes. However, these CD4+ cells were stimulated by influenza virus [8]. The discrepancy of results achieved in the cited works can be justified by a different approach taken to antigenic stimulation.

As well as IL-10, IL-35 is also a suppressive cytokine known to have an inhibitory effect on lymphocyte proliferation and effector Th17 of CD4+ CD25+ cells [5, 6]. Kochetkov et al. have proven the anti-inflammatory effect of IL-35 in CIA in DBA/1 mice in the context of production of IL-10 by CD4+ CD39+ or CD4+ CD39-. Both C57BL/6 and IL-10 -/- mice were administered orally $0.75 \mathrm{mg}$ IL-35 or PBS. Subsequently, CIA was induced in mice. Animals that received IL-35 did not have any characteristic clinical symptoms of CIA [11].

On the other hand, the reduced suppressive activity of Treg cells, as well as their reduced frequency researched under in vitro conditions, is characteristic for patients with autoimmune diseases, including type 1 diabetes, multiple sclerosis [12], and rheumatoid arthritis [13]. The emergence of effective methods of in vitro expansion of polyclonal Treg lymphocytes has made it possible to attempt cellular immunotherapy in animal model diseases and in humans affected by autoimmune diseases, as well as in transplantation medicine [14].

In animal models of autoimmune diseases it was found that adoptive transfer of Treg lymphocytes may effectively inhibit the progression of the disease. Morgan et al. were the first to demonstrate that adoptive transfer of CD4+CD25+ cells in DBA/1 mice in the first stage of CIA development improves the clinical picture of model RA [15]. Moreover, experiments where Treg cells were administered by adoptive transfer have proved successful, both in mouse model of MS [16] and in NOD mice [17]. In our previous research we demonstrated that the adoptive transfer of Treg cells induced under in vitro conditions reduces clinical symptoms of CIA in Wistar rats [18].

Among the many agents used for the induction of the differentiation of CD4+ lymphocytes into iTreg cells, rapamycin and all-trans-retinoic acid (ATRA) seem to be most effective. Under their influence the induced lymphocytes gain stable phenotype of Treg cells that are able to maintain its immunosuppressive function towards the effector lymphocytes. ATRA is thought to regulate the foxp3 gene expression by inducing chromatin decondensation and histone acetyltransferase recruitment in the promoter region. However, ATRA does not always increase foxp3 expression in lymphocytes in the cytokine environment, which assures the differentiation towards Treg [19], but it exerts a positive influence on the induction of other Treg cell features. Among others, it increases the expression of chemokines, assuring their targeted migration, and stabilises foxp3 expression by preventing the disadvantageous transformation into Th17 [20].

On the other hand, the process of Treg cell induction by ATRA may correlate with the expression of nuclear retinoic acid receptors as its natural cellular ligands. There are two types of nuclear retinoic acid receptors: RAR (retinoic acid receptor) and RXR (retinoid $X$ receptor). RAR occurs in three subtypes: RAR $\alpha, \operatorname{RAR} \beta$, and RAR $\gamma$ [21]. Also, three subtypes of RXR are known: $\alpha, \beta$, and $\gamma$. In addition, multiple isoforms of RAR and RXR receptors have been described. They are either synthesised from different promotors (e.g. RAR $\alpha 1$ and RAR $\alpha 2$ ) or produced by alternative splicing. Some of them are inducible by retinoic acid [22].

The RAR family receptors are activated by both alltrans RA (ATRA) and by 9-cisRA, whereas the RXR family is activated exclusively by 9 -cis RA. ATRA, however, is likely to exhibit some RXR-stimulating activity in vitro due to its conversion to 9-cis-RA [23]. RXR can form homo- and heterodimers. After the binding of ATRA with ligands, specific sequences (retinoic acid response sequence) of target gene promoters are activated - RARE for RAR or RXRE for RXR. Specific binding of RA to RAR and RXR homo- or heterodimers takes place in the nucleus where they are constantly present. The process of binding of ligand with protein receptor causes dissociation of repressor protein and binding of the ligand with co-activator.

Very scarce research evidence is available on the presence of RAR and RXR isoforms subtypes in the T lymphocyte and Treg cells. It has been demonstrated that retinoic acid may participate in regulation of its own activity via modulation of the expression of RARs [24].

As has been already described in the literature that blocking of the Rara inhibits differentiation of Tregs in GALT [26-28] which could suggest an important role of this receptor in immune phenomena. In experiments conducted on Rar $-/-$ mice it was demonstrated that the po- 
tential of CD4+CD62+hi to differentiate into Th1 or Th17 is much smaller than the wild type strain. Similarly, the frequency of Tregs present in the small intestinal mucosa is significantly lower in Rar $-/-$ mice compared to the wild-type. As already described by Hall et al., Rara has been identified as an important mediator in the regulatory immune processes [29].

In our experiment, we studied the response of naive CD4+CD25- T cells isolated from healthy rats and from rats with CIA to ATRA under in vitro conditions. We showed that lymphocytes isolated from healthy rats responded differently to ATRA than those isolated from diseased animals. In particular, in diseased animals ATRA significantly increased the transcription of RXR beta and RAR beta in stimulated cells.

\section{Material and methods}

\section{Animals}

Twelve female, six-week-old, inbred Wistar rats weighing 150-200 g from a colony bred at Wroclaw Medical University, Department of Pathology, Poland were used. The experiment was conducted upon permission No. 60/2011 of the Local Ethical Committee II in Wroclaw (Poland). The animals received water and food ad libitum, and were kept at room temperature $\left(24^{\circ} \mathrm{C}\right)$ in an animal facility in a standard microbiological regime in a dark-light cycle (12:12).

\section{Model CIA}

Six experimental animals were immunised twice, subcutaneously at the tail base with $1: 1(\mathrm{v} / \mathrm{v}) 200 \mu \mathrm{g}$ bovine collagen type II (BD Bioscience, USA) and IFA (Freund's Incomplete Adjuvant) (Sigma Aldrich, USA), at a volume of $200 \mu \mathrm{l}$ at a seven-day interval. Another six healthy rats were the control group without any immunisation. The rats were euthanised by inhalational anaesthesia with isoflurane and dislocation of the cervical vertebrae.

\section{Clinical assessment of CIA}

The evaluation of arthritis severity was restricted to the hind paws of the animals, in accordance with the modified and extended numerical scale described by Suszko and Obminska-Mrukowicz [30]. The severity of clinical signs was scored as follows: 0 points - no change; $0-20$ points - swelling of the fingers (0-4 points for each of five fingers); 0-5 points - redness and swelling of the ankle; 0-5 points - redness and swelling in the paw; and $0-10$ points - severe, extensive inflammation of the hind paw multiple joints involved, and/or deformation of joints (ankylosis) with function impairment. The arthritis score for each rat was the average score of both hind paws (the highest score for one hind paw of a rat $=40$ ).

\section{ELISA test}

The level of anti-bovine collagen type II (anti-CII) $\mathrm{IgG}$ antibodies in the sera obtained from immunised and control rats was examined using an ELISA assay. Nunc Maxisorp plates were coated with $2 \mu \mathrm{g} / \mathrm{ml}$ bovine collagen (BD Bioscience, USA) in $0.1 \mathrm{M}$ carbonate buffer, $\mathrm{pH}$ 9.6 , by overnight incubation at $4{ }^{\circ} \mathrm{C}$. The analysed serum was diluted 500-fold in PBS buffer with $0.05 \%$ Tween 20 and incubated at $37^{\circ} \mathrm{C}$ for 1.5 hours. Anti-rat IgG (Jackson ImmunoResearch, USA) conjugated with horseradish peroxidase was used to assess the level of anti-CII antibodies. Supersensitive TMB reagent (Sigma-Aldrich, USA) was used as substrate $(100 \mu \mathrm{l} /$ well $)$. Enzymatic reaction was stopped after 15 minutes with $2 \mathrm{M} \mathrm{H}_{2} \mathrm{SO}_{4}(50 \mathrm{ml} /$ well $)$. The optical density of the wells' content was determined at $\lambda=$ $450 \mathrm{~nm}$ using a BioTek $\mu$ Quantum reader (BioTek, USA).

\section{Flow cytometry}

Lymphocytes were isolated from the spleen and lymph nodes by sieving into PBS. After that, $5 \times 10^{5}$ lymphocytes were suspended in a FACS buffer ( $40 \mathrm{ml}$ PBS, $0.8 \mathrm{ml}$ foetal calf serum [Life Technologies, USA], $40 \mathrm{mg} \mathrm{NaN}_{2}$ ). Cells were stained with anti-rat CD4 FITC (e-Bioscience, USA) and anti-rat CD25-PE (e-Bioscience, USA) for 30 minutes at $4^{\circ} \mathrm{C}$, washed twice with FACS buffer, fixed, and permeabilised with Fix/Perm buffer (e-Bioscience, USA) and permeabilisation buffer (e-Bioscence, USA) in accordance with the manufacturer's instructions. FOXP3 protein was stained with anti-Mouse/Rat FOXP3 Alexa Fluor 647 (e-Bioscience, USA) for 30 minutes at $4^{\circ} \mathrm{C}$. The cells were washed twice with FACS buffer, fixed in $2 \%$ paraformaldehyde and analysed using a FACSCalibur flow cytometer and Weasel 2.0 software. For IL-10 intracellular staining, cells, after extracellular staining by anti-CD4 and anti-CD-25, were cultured at $1 \times 10^{6}$ cells/well, in 24well plates coated with $10 \mu \mathrm{g} / \mathrm{ml}$ anti-CD3 and $1 \mu \mathrm{g} / \mathrm{ml}$ anti-CD28 in the presence of $100 \mathrm{U} / \mathrm{ml} \mathrm{IL-2} \mathrm{in} \mathrm{RPMI} 1640$ medium supplemented with $100 \mathrm{unit} / \mathrm{ml}$ penicillin/streptomycin, $20 \mathrm{mM}$ L-glutamine, $5 \mathrm{ng} / \mathrm{ml}$ TGF- $\beta, 10 \% \mathrm{FCS}$, and with $1 \mu \mathrm{l} / 1 \times 10^{6}$ cells Golgi Plug, $50 \mathrm{ng} / \mathrm{ml}$ PMA, and $1 \mu \mathrm{g} / \mathrm{ml}$ ionomycin, with or without $10 \mathrm{nM}$ ATRA. After incubation the cells were washed twice with $2 \mathrm{ml}$ of $\mathrm{PSB}+2 \%$ FBS, fixed, and permeabilised with Fix/Perm buffer (e-Bioscience, USA) and permeabilisation buffer (e-Bioscence, USA) in accordance with the manufacturer's instructions. Then cells were stained with anti-rat IL-10 PE (BD Bioscience, USA) for 30 minutes at $4{ }^{\circ} \mathrm{C}$. The cells were washed twice with FACS buffer, fixed in $2 \%$ paraformaldehyde and analysed using a FACSCalibur flow cytometer and Weasel 2.0 software.

\section{FACS sorting}

Lymphocytes isolated from the spleen and the lymph nodes of healthy or CIA rats were mixed together and sus- 
pended in PBS $+2 \%$ foetal calf serum (FCS) and stained with rat anti-CD4 FITC (e-Bioscience, USA), anti-rat CD25-PE (e-Bioscience, USA) for 30 minutes at $4^{\circ} \mathrm{C}$. The cells were then washed twice with PBS $+2 \%$ FCS, and disaggregated in sterile FACS tubes with a $35-\mu \mathrm{m}$ nylon mesh cell strainer cap (BD Biosciences, USA). $50 \times 10^{6}$ cells prepared in this manner were sorted by CD4+CD25phenotype on the BD FACSAria II at 15,000 cells/second. Following sorting, the CD4+CD25- cells were immediately centrifuged in PBS $+2 \%$ FCS.

\section{Culture of CD4+CD25- cells}

After sorting, the cells were cultured for four days at $1 \times 10^{6}$ cells/well, in 24-well plates coated with $10 \mu \mathrm{g} / \mathrm{ml}$ anti-CD3 and $1 \mu \mathrm{g} / \mathrm{ml}$ anti-CD28 in the presence of 200 $\mathrm{U} / \mathrm{ml}$ interleukin-2 in RPMI 1640 medium supplemented with $100 \mathrm{unit} / \mathrm{ml}$ penicillin/streptomycin, $20 \mathrm{mM} \mathrm{L-glu-}$ tamine, $5 \mathrm{ng} / \mathrm{ml}$ TGF- $\beta, 10 \%$ FCS and with or without $10 \mathrm{nM}$ of all-retinoic acid (Sigma Aldrich, USA). Dosage of ATRA was tested according to data from the literature [31]. The control culture had no ATRA.

\section{Isolation of mRNA}

Cells isolated from the spleen and lymph nodes from healthy or diseased rats after being sorted according to the CD4+CD25- phenotype and after culturing in the presence of or without $10 \mathrm{nM}$ ATRA in a quantity of $0.5 \times 10^{6}$ were suspended in $0.5 \mathrm{ml}$ TriReagent and stored at $-20^{\circ} \mathrm{C}$ until the time of isolation (no longer than one month). The RNA isolation procedure was tested in pilot researches and the highest quality was obtained with the Qiagen Rneasy Mini Kit (50) (catalogue number 74104, Qiagen, USA); however, the procedure proposed by the producer was modified and the RNA isolation was performed in a manner described further. RW1 and RPE are buffers included in the Qiagen Rneasy Mini Kit (50). First, the samples were defrosted and $0.2 \mathrm{ml}$ of chloroform was added. The sample was intensively stirred for 15 seconds and incubated for five minutes at room temperature and then centrifuged at $12,000 \times \mathrm{g}$ for 15 minutes at $4^{\circ} \mathrm{C}$.

The RNA water phase was collected to a sterile Eppendorf tube and one volume of $70 \% \mathrm{EtOH}$ was added. After stirring, and the whole sample was moved to a centrifugal column centrifuged for 15 seconds at $8000 \mathrm{~g}$ at room temperature. Then $350 \mu \mathrm{l}$ of the RW1 buffer was added on the centrifugal column and centrifuged for 15 seconds at $8000 \mathrm{~g}$ at room temperature. The next step was the digestion of genomic DNA remains. For this purpose, a solution was prepared according to the manufacturer's instructions (Dnase I, nr cat. EN0525, Fermentas, USA) in the amount of $20 \mu \mathrm{l}$ per sample of the reaction mixture and incubated for 15 minutes at $37^{\circ} \mathrm{C}$. Afterwards, $350 \mu$ l of RW1 buffer was added, centrifuged for 15 seconds at $8000 \mathrm{~g}$ at room temperature. $500 \mu \mathrm{l}$ of RPE Buffet was addend and centri- fuged for 15 seconds at $8000 \mathrm{~g}$ at room temperature, and then the column was placed in a new Eppendorf tube. $50 \mu \mathrm{l}$ of $\mathrm{H}_{2} \mathrm{O}_{\mathrm{RNase}}$ free was applied and centrifuged for one minute at $8000 \mathrm{~g}$ at room temperature. RNA concentration was determined with Nano Drop 2000.

\section{RT-PCR}

The reversed transcription reaction (RT-PCR) was conducted with the use of a RT-PCR device - High Capacity cDNA Reverse Transcription Kit (catalogue no. 4368814, Applied Biosystems, USA) in the MJ Mini Personal Thermal Cycler BIORAD apparatus. The RT-PCR reaction was conducted at the RNA matrix, $2 \mu \mathrm{g}$ per reaction. RNA solution was added in the amount of $10 \mu \mathrm{l}$ to $10 \mu \mathrm{l}$ of the reaction mixture. Samples were cooled in ice, and reversed transcription reaction was conducted for five minutes at $25^{\circ} \mathrm{C}$, then for 120 minutes in $37^{\circ} \mathrm{C}$, and five seconds at $85^{\circ} \mathrm{C}$.

\section{Real-time PCR}

The expression of $f \circ x p 3, \operatorname{rar} \alpha, \operatorname{rar} \beta$, and $\operatorname{rxr} \beta$ genes was determined by the Real-time PCR method in the Applied Biosystems 7300/7500 Real Time PCR System apparatus with a relative method, with $\beta$-act as a reference gene. The reaction mixture consisted of $10 \mu 12 \times$ TaqMan Gene expression Master Mix, $1 \mu$ of TaqMan probe, $8 \mu \mathrm{H}_{2} \mathrm{O}_{\mathrm{RNase}}$ free, and $1 \mu \mathrm{l} \mathrm{cDNA.} \mathrm{Reaction} \mathrm{program:}$ preliminary $50^{\circ} \mathrm{C}$, one cycle, two minutes; denaturation $95^{\circ} \mathrm{C}$, one cycle, 10 minutes, 40 cycles: denaturation $95^{\circ} \mathrm{C}$ $0: 15$ minutes, elongation $60^{\circ} \mathrm{C}$ one minute. A formula was used for the calculations (Livak and Schmittgen, 2001). TaqMan probes made by Life Technologies company: $\beta$-act (Rn00667869_m1), foxp3 (Rn01525092_m1), rara (Rn00580551_m1), $\operatorname{rar} \beta$ (Rn01537837_m1), $\operatorname{rxr} \beta$ (Rn01399560_m1) were used. Real Time PCR System SDS Version 1.4 was the computer software used.

\section{BCA}

A Bicinchoninic Acid Protein Assay Kit (BCA kit) (Sigma Aldrich, USA) was used for the determination of protein concentration in the prepared samples. For this purpose, a $1: 50$ mixture of copper sulphate solution (II) and bicinchoninic acid solution was prepared. $25 \mu \mathrm{l}$ of the examined protein was added to $200 \mu \mathrm{l}$ of the mixture, and incubated for 30 minutes at $37^{\circ} \mathrm{C}$. Next, the absorbency of the research sample against control sample was measured at wavelength $\lambda=550 \mathrm{~nm}$. The protein concentration was determined based on a standard curve of bovine serum albumin in a concentration of $0.1-1 \mathrm{mg} / \mathrm{ml}$.

\section{Western blotting}

Freshly isolated from all the groups being examined $(n=6)$ and sorted CD4+CD25- cells were washed twice with ice-cold PBS and homogenised in RIPA buffer (Sig- 
ma Aldrich, Poland) supplemented with Protease Inhibitor Cocktail III (Merck Millipore, Germany). Then the samples were incubated for 30 minutes on ice and centrifuged twice at $8000 \mathrm{~g}$ for 10 minutes to collect the supernatant, which was frozen at $-80^{\circ} \mathrm{C}$ and stored until later use. The total protein concentration was determined using Bicinchoninic Acid Protein Assay Kit (Sigma Aldrich, Poland) according to the manufacturer's instructions. Cell lysates were mixed with 4xTris-glycine-SDS sample buffer $(62.5$ $\mathrm{mM}$ Tris- $\mathrm{HCl}, 2 \%$ SDS, $10 \%$ glycerol, $5 \%$ mercaptoethanol, $0.015 \%$ bromophenol blue) and boiled for five minutes. Samples ( $25 \mu \mathrm{g}$ per well) were then separated on $12 \%$ SDS-polyacrylamide gels and transblotted $(350 \mathrm{~mA}, 90$ minutes, cold) onto nitrocellulose membranes $(0.45 \mu \mathrm{m}$ pore size). The membranes were blocked overnight with $5 \%$ non-fat dry milk in Tris-buffered saline (pH 7.4) at $4^{\circ} \mathrm{C}$ with gentle shaking. After washing three times with TBS with $0.2 \%$ Triton $\mathrm{X}-100$, the blots were incubated for 90 minutes at RT with mouse monoclonal antibody against RXR $\beta$ (sc-742, Santa Cruz, Dallas, USA), rabbit polyclonal antibody against RAR $\beta$ (sc-552, Santa Cruz, Dallas, USA), and rabbit polyclonal antibody against RAR $\alpha$ (sc-551, Santa Cruz, Dallas, USA). All antibodies were used at a 1:500 dilution in TBS with $0.2 \%$ Triton X-100 and non-fat dry milk. After washing three times with TBS with $0.2 \%$ Triton X-100 and non-fat dry milk, the membranes were incubated for one hour at RT with a goat polyclonal secondary antibody against rabbit IgG conjugated with HRP (Santa Cruz, Dallas, USA) and rabbit polyclonal secondary antibody against mouse IgG conjugated with HRP (Santa Cruz, Dallas, USA). Secondary antibodies were used at a dilution of $1: 100$ in TBS with $0.2 \%$ Triton X-100 and non-fat dry milk. After incubation the membranes were washed twice with TBS with $0.2 \%$ Triton X-100. Detection was performed using a WesternBright Quantum HRP (Advansta, USA) and images were captured using a GBOX imaging system (Amersham Pharmacia, Piscataway, New Jersey, USA). Densitometric analysis was performed with ImageJ software (NIH). Membranes were normalised with a rabbit monoclonal $\beta$-Actin (Cell Signaling, USA).

\section{Tissue material}

Peripheral blood for serological examination was collected from the hearts of the anaesthetised animals before euthanasia. Spleen (SPL), popliteal (PN), mesenteric (MN), inguinal (IN), and axillary lymph nodes (AXN) were dissected from the euthanised animals. Then the hind paws were dissected and fixed in buffered $4 \%$ formalin in PBS.

\section{X-ray}

X-ray examination was performed after euthanasia of rats, using a Gierth HF 90/20 X-ray unit and conventional $\mathrm{X}$-ray film (Aqua Mamoray HD). Each animal underwent examination of both distal hind limbs in a dorso-plantar plane. The following radiographic abnormalities were considered: $\mathrm{a}$ - soft tissue swelling; $\mathrm{b}$ - narrowing/widening of joint space; $\mathrm{c}$ - subchondral bone erosions according to modified Larsen classification: 0 - normal; 1 - distinct focal osteolysis in some joint areas; 2 - highly visible osteolysis in some joint areas; 3 - total bone erosion in a joint area, $\mathrm{D}$ - joint degeneration, $\mathrm{N}$ - normal ankle joint.

\section{Histology}

Formalin-fixed sections of joints were embedded in paraffin blocks, sliced and stained with Delafield's haematoxylin-water eosin. Preparations were viewed and evaluated using a BX53 Olympus microscope. Digital photos were taken with an Olympus Colorview IIIu camera.

\section{Statistical analysis}

Research was performed in one experiment and there were six rats in every group, constituting an independent experimental system. Results were analysed using Statistica software, version 10.0, by analysis of variance (ANOVA) and Duncan's post-hoc test for statistical significance, with significance levels of $p<0.05$ and $p<0.01$. Groups were compared between healthy or CIA group and control or ATRA option of in vitro cell culture analysis.

\section{Results}

\section{Clinical, serological, and histological evaluation of rats with CIA}

Six-week old female Wistar rats were divided into two groups (healthy and with CIA) of 6 animals per group. The stage of CIA was evaluated by an algorithm with a scale from 0 to 40 points. On the $21^{\text {st }}$ day of observation, when the animals were euthanised, the average number of points according to the adopted evaluation scale for rats with CIA was $30 \pm 6$ (left hind limb) and $32 \pm 6$ (right hind limb) (Fig. 1A). No macroscopic changes were found among healthy rats (Fig. 1B).

Both the healthy rats and those with CIA were examined for the level of specificity of the antibody response to the type-II bovine collagen (anti-CII), with which the animals were immunised in order to trigger CIA. In rats with CIA it was $0.8 \pm 0.23$ level OD units on the $21^{\text {st }}$ day. Healthy rats had no anti-CII antibodies (Fig. 2).

Histological analysis of rats with CIA has shown an increase in the number of blood vessels in the subependymal layer and inflammatory infiltrates of mononuclear cells were observed, localised mainly around vessels (++), mainly lymphocytic (also some plasmatic cells and macrophages), cells proliferation of the subependymal layer (synoviocytes), and focal villi proliferation (Fig. 3B). Normal 
A

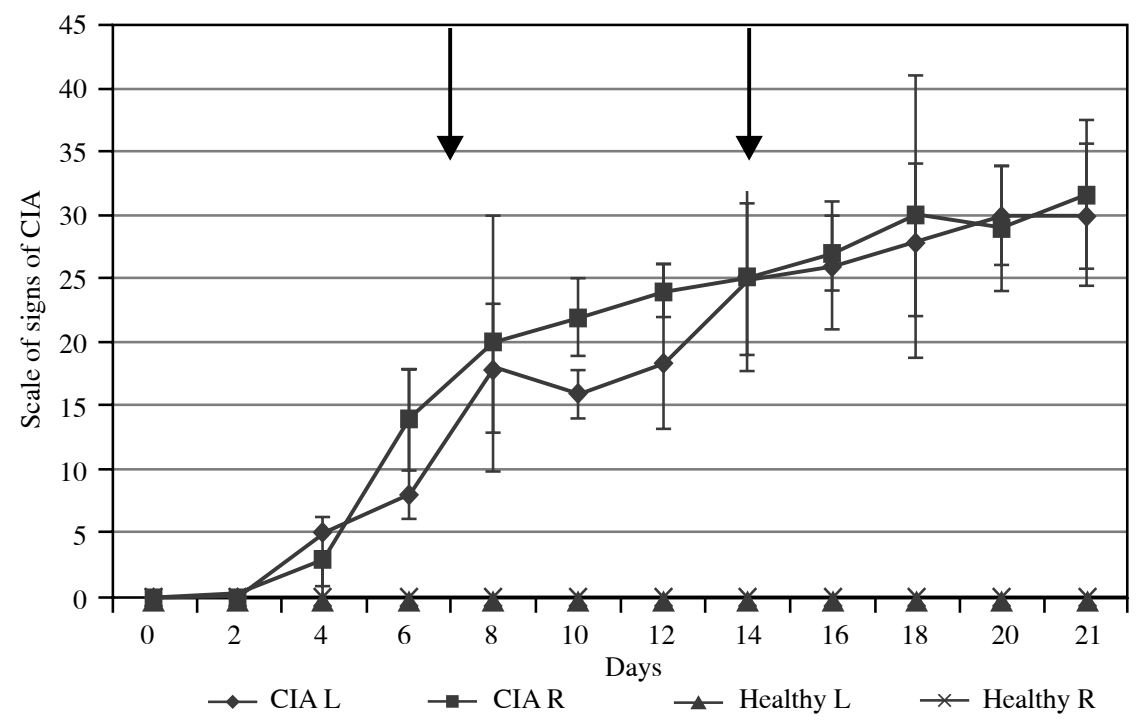

B
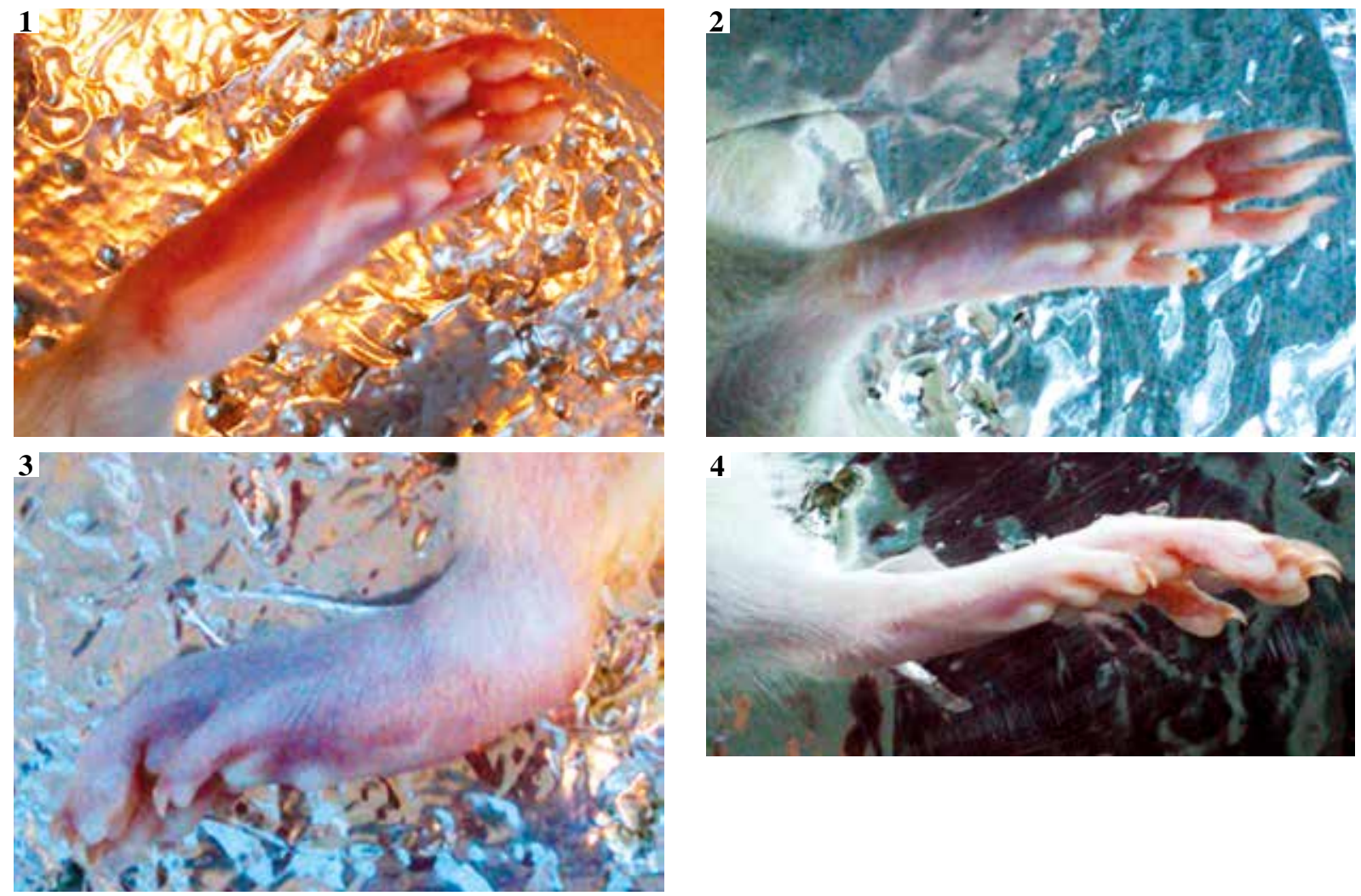

Fig. 1. A) Development of CIA symptoms in healthy rats (Healthy) and in rats with CIA (CIA). The evaluation of arthritis severity was restricted to the hind paws - left $(\mathrm{L})$ and right $(\mathrm{R})$ - of the animals, in accordance with the modified and extended numerical scale described by Suszko and Obminska-Mrukowicz [30]. Arrows are marking days of immunization. Rats from the group $\mathrm{H}$ did not show any symptoms of the disease (data not shown). Arrows indicate days on which the rats were immunized. B) Images of hind limbs of healthy rats (2 and 4), and rats with CIA (1 and 3) 
rats, however, did not show any histopathological changes (Fig. 3A).

Radiographic examination of animals with CIA showed changes typical for rheumatoid arthritis with osteolysis - swelling of the soft tissue surrounding the joint, thinned and blurred image of the tarsal bones in the joint, and osteolysis of the tarsal bones (Fig. 4B). No lesions were observed in healthy animals (Fig. 4A).

Popliteal, inguinal, axillary lymph nodes, and spleen were isolated from rats after their euthanasia. Among isolated lymphoid organs, popliteal lymph nodes stood out macroscopically - they were larger in animals with CIA than in healthy animals (data not shown).

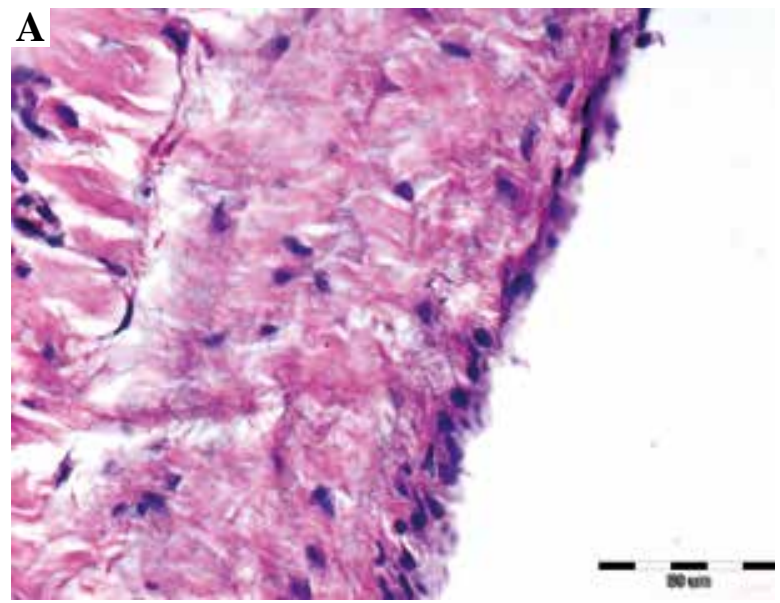

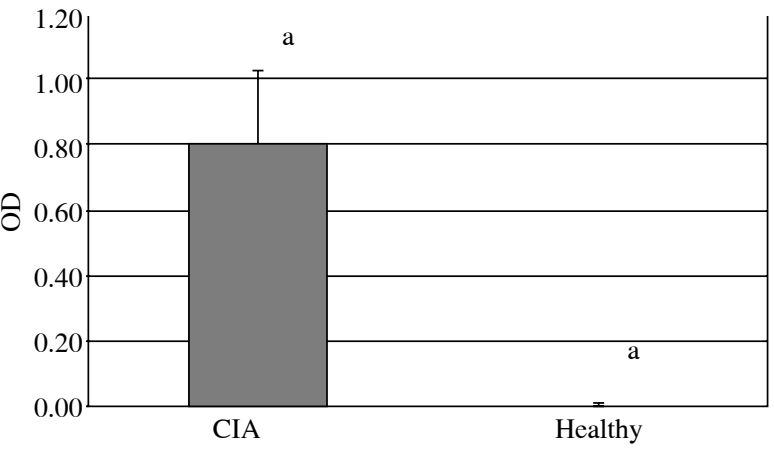

Fig. 2. The level of anti-CII antibodies in healthy rats and rats with CIA. $N=6$, the same letters indicate statistically significant differences - lower case letters indicate significant differences at $p<0.01$ (OD - optical density)

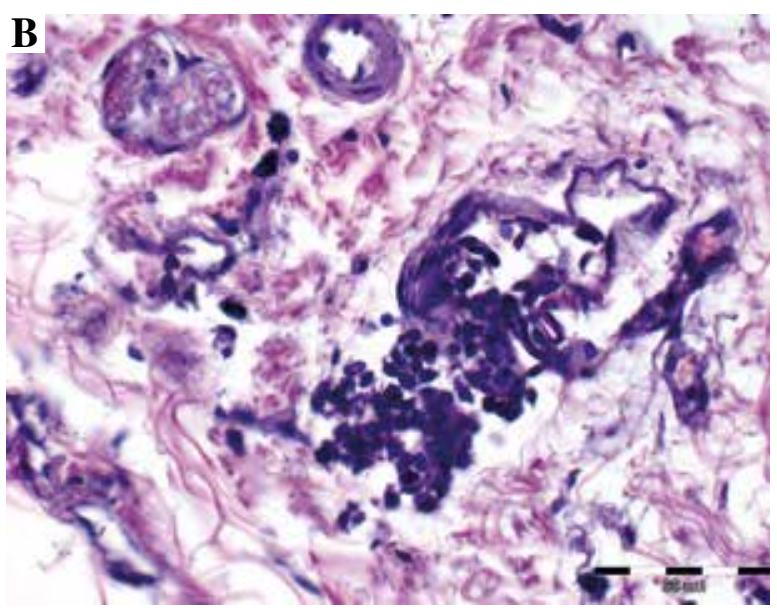

Fig. 3. Representative images from histological analysis of periarticular tissues in healthy rats (A) and rats with CIA (B). In rats with CIA has been investigated an increase in the number of blood vessels in the subependymal layer and inflammatory infiltrates of mononuclear cells were observed (B). However normal rats, did not show any histopathological changes (A)
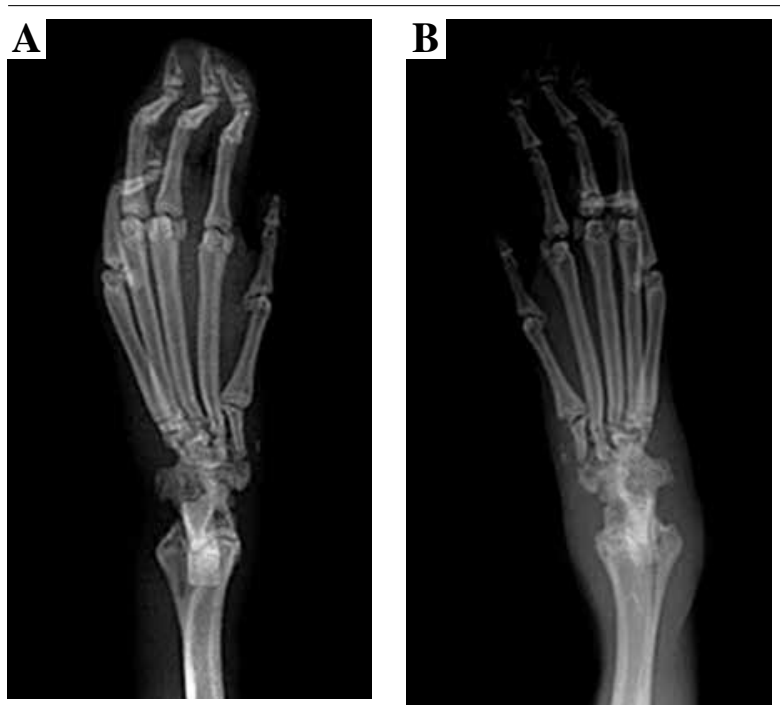

Fig. 4. Representative X-ray images of joints from healthy rats (A) with normal ankle joint and rats suffering from collagen-induced arthritis (CIA) with total bone erosion in a joint area 


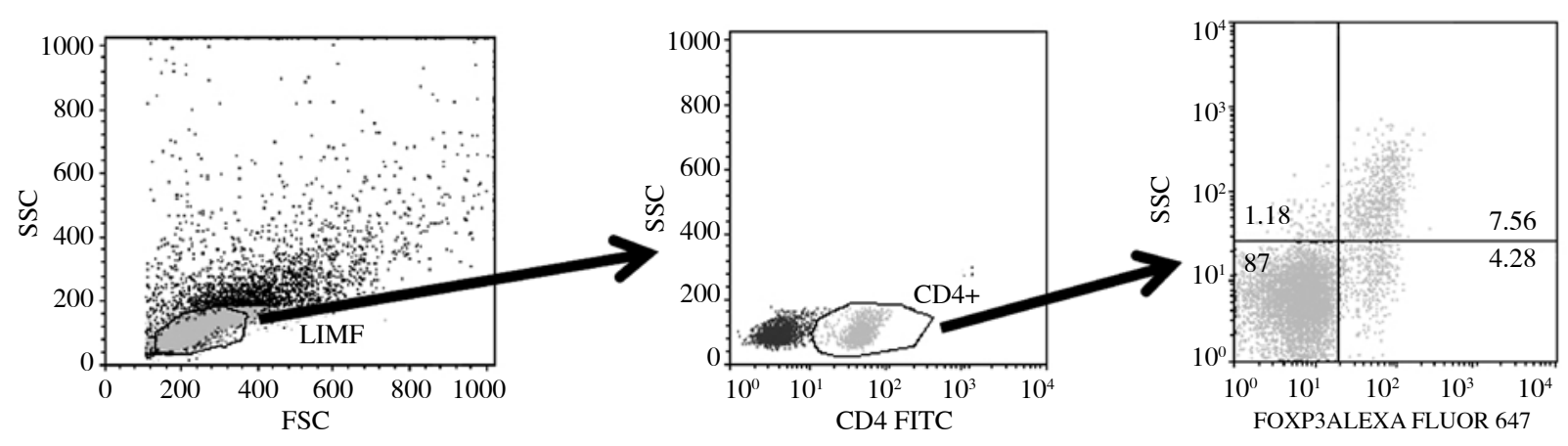

Fig. 5. The method of analysis of the CD4+CD25+FOXP3+ cells frequency

\section{Flow cytometric analysis of the}

\section{CD4+CD25+FOXP3+ cells after culture in the presence of ATRA}

The frequency of regulatory $\mathrm{T}$ cells characterised by the CD4+CD25+FOXP3+ phenotype were analysed according to the scheme presented in Fig. 5. Cells were analysed by a lymphocyte gate on an SSC/FSC diagram and subsequently by an SSC/CD4 gate. The percentage of CD25+FOXP3+ cells was determined in the selected population of CD4+ cells.

CD4+CD25- cells isolated from animals and subjected to culture under in vitro conditions in the presence of ATRA or without ATRA (Control) in a group of animals with CIA differentiated more efficiently $(p<0.05)$ into regulatory $\mathrm{T}$ cells with the CD4+CD25+FOXP3+ phenotype $(47.19 \pm 17.42 \%$ in the ATRA group and 45.23 $\pm 13.39 \%$ in the control group), than cells isolated from healthy animals $(27.22 \pm 7.61 \%$ in the ATRA group and $27.23 \pm 10.63 \%$ in the control group) (Fig. 6).

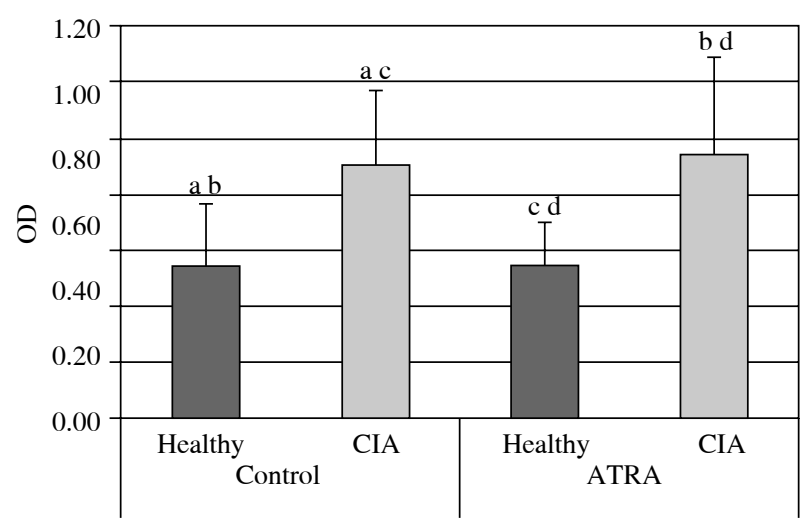

Fig. 6. Frequency of CD4+CD25+FOXP3+ lymphocytes in the population of CD4+ cells after the culture of CD4+CD25- isolated from normal rats (Healthy group) and rats with CIA (CIA group), in the presence of ATRA (ATRA) and without ATRA (K); $n=6$, the same letters indicate statistically significant differences at $p<0.05$

\section{Determination of the capacity of CD4+CD25- cells to differentiate towards the CD4+FOXP3+IL-10+ phenotype after sorting and culturing in the presence of ATRA or in control culture}

Cells isolated from the lymph nodes and spleens of healthy animals as well as from those with CIA were subjected to sorting in order to obtain a CD4+CD25- population, with an average purity of population of 93.05 $\pm 3.81 \%$. The frequency of regulatory $\mathrm{T}$ cells with the CD4+FOXP3+IL-10+ phenotype was analyzed according to the scheme presented in Fig. 7.

The highest capacity of differentiation into the CD4+FOXP3+IL-10+ phenotype was exhibited by the cells isolated from healthy animals cultured in vitro without the addition of ATRA $(15.91 \pm 8.45 \%)$. However, a significant difference $(p<0.05)$ was observed only in comparison to cells isolated from rats with CIA and cultured with ATRA $(4.70 \pm 2.49 \%)$ (Fig. 8).

\section{Determination of the gene expression of foxp3, $\operatorname{rar} \alpha, \operatorname{rar} \beta$, and $\operatorname{rxr} \beta$ genes in CD4+CD25- cells after ATRA stimulation}

The gene expression clearly changed after adding CD4+CD25- cells to the culture with 10 nM ATRA. The highest expression of foxp 3 gene was observed in cells isolated from healthy rats and cultured in the presence of $10 \mathrm{nM}$ ATRA. The expression of foxp 3 in those cells was significantly higher than that in the CD4+CD25 cells examined directly after sorting, as well as after culture without ATRA $(p<0.05)$, but not in cells isolated from CIA animals cultured in the presence of ATRA (Fig. 9A).

The relative rar $\alpha$ expression clearly and significantly (at $p<0.01$ ) increased in culture of the CD4+CD25cells in the presence of ATRA both in healthy animals and those with CIA in comparison to other examined groups of cells (i.e. directly after sorting and cultured 

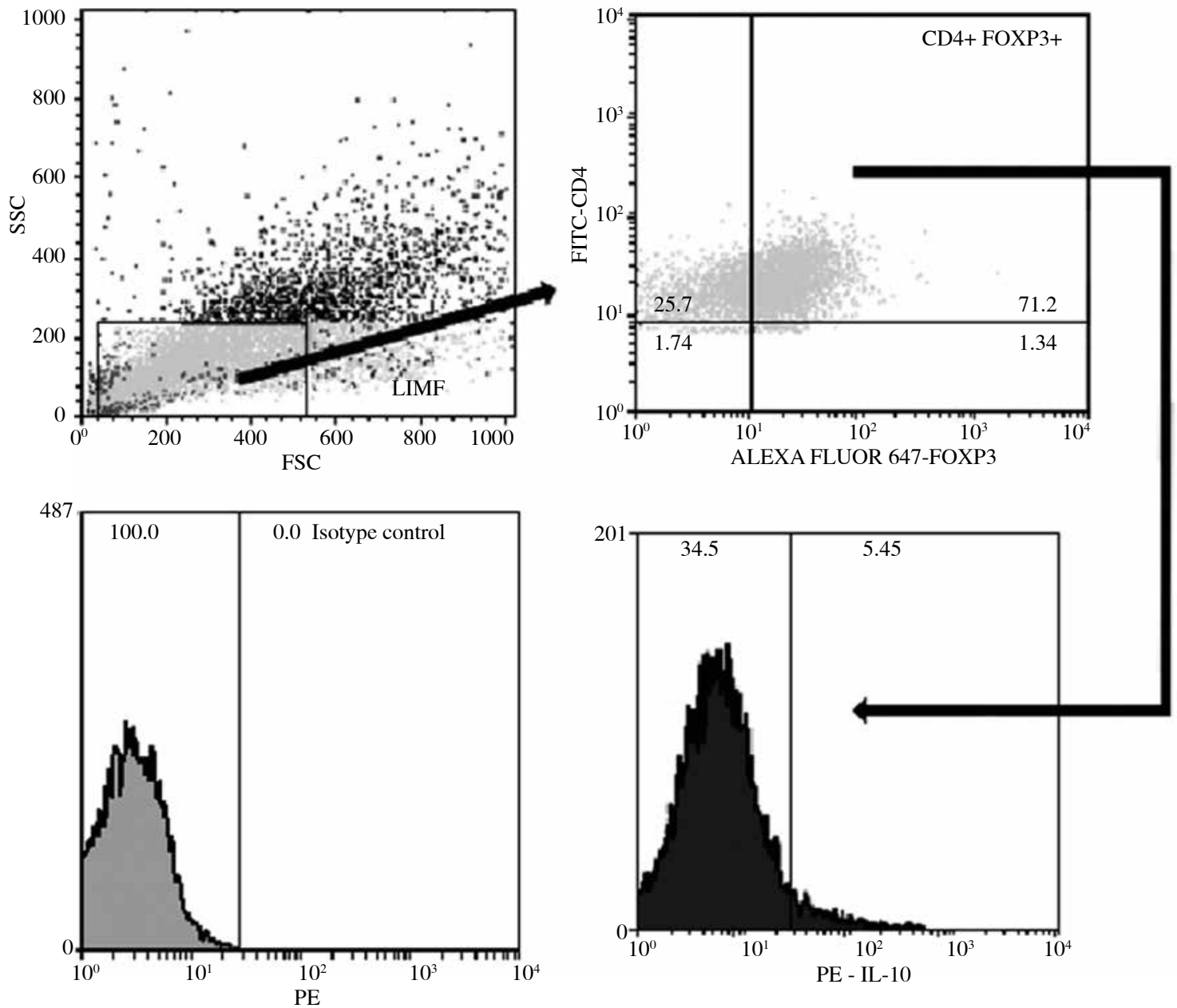

Fig. 7. Method of analysis of the CD4+ FOXP3+IL-10+ cells frequency. Cells were analyzed using a lymphocyte gate on a SSC/FSC graph, and using a SSC/CD4 gate in next step. Then CD4+ cells were analyzed using a CD4+FOXP3+ gate and $\mathrm{CD} 4+\mathrm{FOXP} 3+$ cells were gated and analyzed in the last stage in a histogram, where IL-10+ cells were gated

w/o ATRA). No statistically significant differences were observed between CD4+CD25- cells cultured in vitro in the presence of ATRA isolated from healthy animals and those isolated from animals with CIA (Fig. 9B).

The highest expression of $\operatorname{rar} \beta$ gene was observed in cells isolated from rats with CIA cultured in the presence of ATRA in comparison with the expression in cells cultured without ATRA addition, both in healthy and diseased rats and in comparison with cells examined directly after sorting and isolated from healthy animals $(p<0.05)$ (Fig. 9C).

The expression of $\operatorname{rxr} \beta$ gene was similar to the expression profile of the $r \alpha r \beta$ gene. The highest expression was observed in cells isolated from rats with CIA cultured under in vitro conditions in the presence of ATRA, which indicated statistically significant differences at $p<0.05$ compared to control cultures without ATRA, both for healthy and diseased rats and against cells isolated from healthy animals after sorting (Fig. 9D).

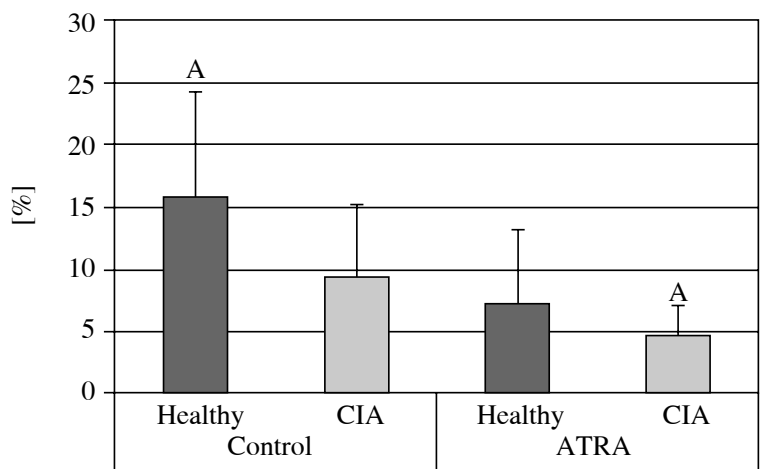

Fig. 8. Frequency of CD4+FOXP3+IL-10+ cells differentiated from CD4+CD25- cells (isolated from the spleen, popliteal, inguinal, mesenteric, and subbrachial lymph nodes, sampled from healthy rats [Healthy group] and rats with CiA [CIA group]) in vitro and in the presence of $10 \mathrm{nM}$ ATRA (ATRA) and without ATRA (Control); $n=6$, the same letters indicate statistically significant differences at $p<0.05$ 

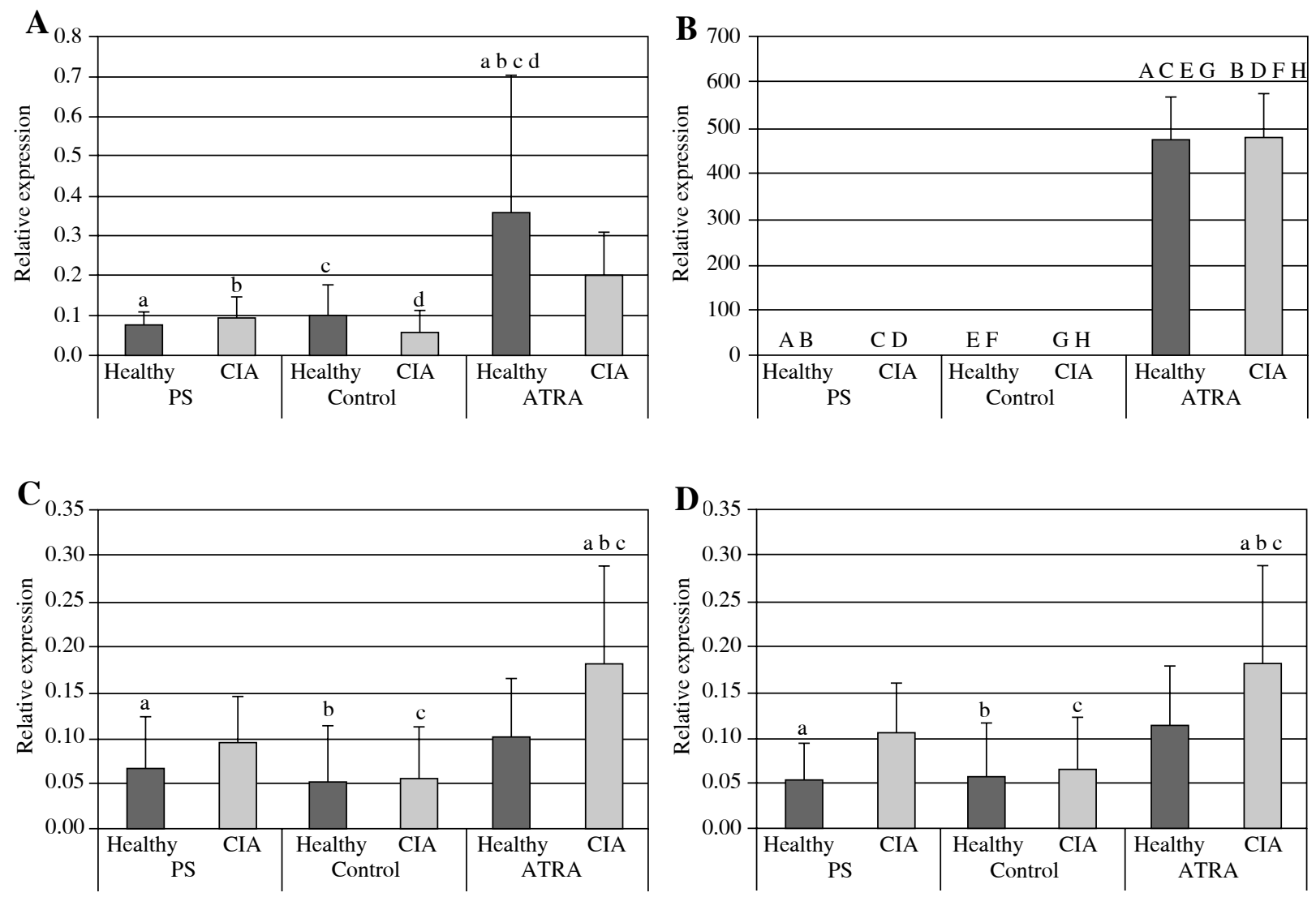

Fig. 9. Analysis of changes in the expression of Foxp3 (A), $\operatorname{rar} \alpha(B), \operatorname{rar} \beta(C), \operatorname{rxr} \beta$ (D) genes in comparison to $\beta$-actin reference gene, in healthy rats and rats with CIA after sorting the CD4+CD25- (PS) cells from the lymph nodes and spleen after cell culture in RPMI medium with IL-2 and TGF- $\beta$ without the addition of ATRA (K) and after cell culture in RPMI medium with IL-2 and TGF- $\beta$ with the addition of $10 \mathrm{nM}$ ATRA (ATRA). Gene expression was determined by real-time PCR (TaqMan). Capital letters indicate significance at $p<0.01$ and lowercase letters indicate significance at $p<0.05$. The same letters indicate significance between pairs of results

\section{The expression of $\operatorname{Rar} \alpha, \operatorname{Rar} \beta$, and $\operatorname{Rxr} \beta$ protein}

Due to the fact that a high number of cells are needed for protein expression examination, and taking into account the efficiency of cell sorting, differentiation rates, and animal care regulations, the investigations on Rar $\alpha$, $\operatorname{Rar} \beta$, and $\operatorname{Rxr} \beta$ protein expression were restricted only to CD4+CD25- cells sorted from lymph nodes and spleen in healthy animals and in animals with CIA. Protein expressions were examined against $\beta$-actin as the reference protein (Fig. 10).

When comparing the expression of the retinoic acid receptors in the CD4+CD25- cells isolated from healthy rats and rats CIA, a statistically significant difference was observed for the expression of $\operatorname{Rxr} \beta(p=0.003) \operatorname{Rxr} \beta$ expression was not observed in healthy animals, while in animals with CIA the ratio of $\beta$-actin to $\operatorname{Rxr} \beta$ was 0.96 \pm 0.18 . As for Rar $\alpha$, higher expression of this protein was observed in animals with CIA than in healthy animals
$(1.43 \pm 0.73 \beta$-actin to Rar $\alpha$ ratio in animals with CIA and $0.88 \pm 0.18 \beta$-actin to Rar $\alpha$ ratio in healthy animals).

On the other hand, a higher $\operatorname{Rar} \beta$ expression was observed in healthy animals $(2.53 \pm 1.76 \beta$-actin ratio) when compared to animals with CIA $(1.08 \pm 0.10$ of $\beta$-actin ratio). No statistically significant differences in Rar $\alpha$ and $\operatorname{Rar} \beta$ expression were observed between healthy animals and those with CIA; nevertheless, comparing obtained results between the groups reveal varying tendency towards the expression of examined retinoic acid receptors within examined groups (Fig. 11).

\section{Discussion}

The presence of ATRA in the milieu of CD4+CD25cells isolated from animals with CIA and from healthy animals differentially affects Treg cell frequency and foxp3 gene expression. 
A
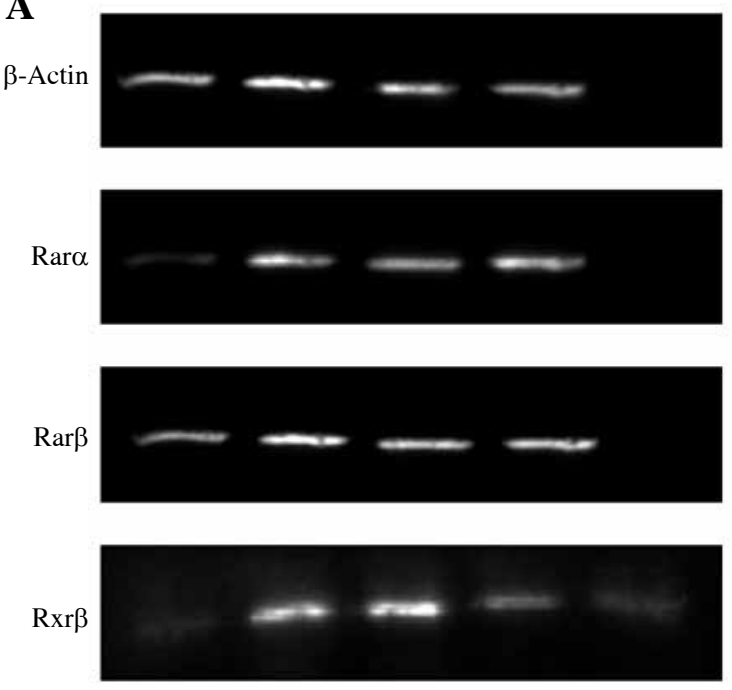

B

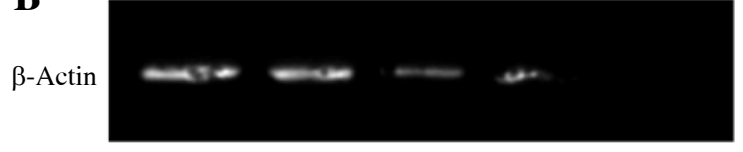

Rar $\alpha$

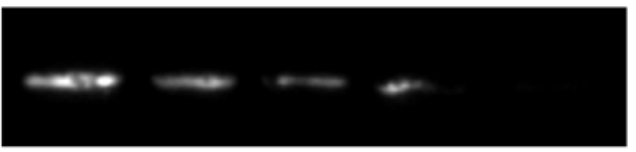

$\operatorname{Rar} \beta$

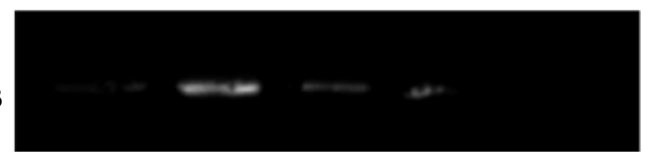

Fig. 10. The results of the $\operatorname{Rar} \alpha, \operatorname{Rar} \beta$ and $\operatorname{Rxr} \beta$ proteins expression determined by Western blotting against $\beta$-actin as reference protein in healthy animals and animals with CIA. Proteins expression was determined in cells isolated from the spleens and lymph nodes (popliteal, inguinal, mesenteric, and axillary) from normal rats and rats with the CIA. A) rats with CIA; B) healthy rats

In the course of model RA, an increase in the population of Treg cells may be obtained by intraperitoneal infusion of ATRA, which results in the alleviation of disease symptoms [32]. Moreover, CD4+CD25- cells isolated from healthy mice and cultured in vitro in the presence of ATRA differentiate into CD4+CD25+FOXP3+ cells. These observations indicate that ATRA induces the differentiation of cells into Treg lymphocytes both in healthy animals and in the course of developing model RA. It also supports Treg lymphocytes phenotypic and functional stability in the presence of proinflammatory cytokines [33]. The results of our research indicated that foxp 3 gene expression was strongly induced in CD4+CD25- cells under the influence of $10 \mathrm{nM}$ ATRA stimulation in healthy rats only.

Retinoic acid has a profound impact on cell proliferation, metabolism and differentiation. ATRA, as mentioned above, is also a potent stimulator of Treg differentiation [19]. On the other hand, its effectiveness as the stimulator of Treg differentiation may be related to the initial metabolic status of progenitor cells used for Treg cells expansion under in vitro conditions. It has been demonstrated that severe metabolic modifications and cell senescence are involved in the pathogenesis of autoimmune diseases involving rheumatoid arthritis [34].

However, in our experiment we did not observe any supportive role of ATRA in differentiation of CD4+CD25into Treg cells under in vitro conditions both in healthy animals and in rats with CIA. On the other hand, these cells were significantly prone to develop into Treg cells in rats with CIA. The mechanism of this phenomenon is not clear. However, the differential metabolic states of healthy and diseased animals should be taken into consideration. It was showed by Yang et al. that glycolytic activity of naive $\mathrm{T}$ lymphocytes in patients with rheumatoid arthritis is lower than in a healthy control group [34].

Moreover, in chronic inflammatory diseases like in rheumatoid arthritis, insulin resistance is observed and cellular glucose uptake is inhibited [35]. On the other hand, contrary to T effector cells where glycolysis promotes their development and differentiation $\mathrm{T}$ regulatory cell induction is independent of glycolysis and relies on lipid oxidation [36]. Therefore, paradoxically, the metabolic state of diseased animals may promote differentiation of naive CD4+ lymphocytes into Treg.

\section{CD4+CD25- cells cultured in vitro in the presence of ATRA indicate different potential to propagate towards CD4+FOXP3+IL-10+ phenotype cells}

Interleukin 10 is a suppressive cytokine. Treg cells produce IL-10, assuring the immunosuppressive mechanism of attenuation of autoimmune phenomena, including RA [37].

In our research we observed that in in vitro cultures of CD4+CD25- cells isolated from healthy animals and conducted in the presence of ATRA, the frequency of CD4+FOXP3+IL-10+ cells was statistically significantly higher than in cultures of cells isolated from animals with CIA.

In view of the available literature, the correlation between the release of IL-10 by iTregs differentiated from 


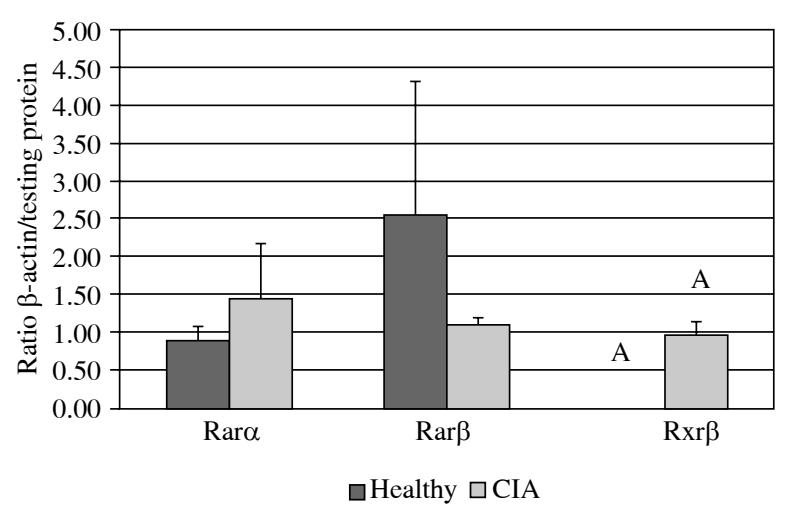

Fig. 11. Comparison of $\operatorname{Rar} \alpha, \operatorname{Rar} \beta$ and $\operatorname{Rxr} \beta$ protein expression in healthy animals and animals with the CIA. Proteins were determined in cells isolated from the spleens and lymph nodes (popliteal, inguinal, mesenteric, and subbrachial) from normal rats and rats with the CIA. $N=4$; These same letters indicate significance between pairs of results. Significance at $p=0.003$

CD4+CD25- cells subjected to culture under in vitro conditions in the presence of ATRA and those cultured without the addition of ATRA, is not clear. CD4+ lymphocytes cultured in the presence of LE540 (RAR antagonist) significantly increases the release of IL-10. The results of our research, where the highest release of IL-10 was from cells isolated from healthy animals cultured in vitro with no ATRA added, confirm the inhibitory effect of ATRA on the synthesis of IL-10 [38]. Therefore, an assumption can be made that the observed immunosuppressive effects of iTreg cells in the course of CIA may be the result of triggering suppressive mechanisms independent from IL-10.

\section{Rar $\alpha$ expression is increased in induced Treg cells in the presence of ATRA}

Little is known about the differences in the expression of retinoic acid receptors on the gene and protein levels between healthy and diseased individuals. So far, the role of rar $\alpha$ in promyelocytic leukaemia (APL) has not been described in detail. However, it was demonstrated that in the pathomechanism of APL, translocation of the arms of chromosomes 15 and 17 takes place, which results in the fusion of PML/RAR $\alpha$ transcripts. PML/RAR $\alpha$ protein may behave like a transcription factor dependent on ATRA, which leads to the development of an effective pharmacotherapy, where an oral supply of ATRA decreases pathophysiology of APL [39].

Moreover, in lymphocytes the regulation of retinoic acid receptor expression under the influence of their natural ligand- ATRA is complicated because of differential constitutive expression of their isoforms and accessibility of functional RARE in promoter regions of their genes [25].
Our research have shown a significant increase in raro gene expression in CD4+CD25- cells cultured in vitro in the presence of $10 \mathrm{nM}$ ATRA, in both healthy and diseased animals. However, no differences in rar $\alpha$ expression between healthy and diseased animals were observed. The TaqMan sequence we used in our experiment did not allow us to indicate which isoform of RARalpaha (1 or 2) is expressed. However, as indicated by Takayema et al. in rat embryos [40] and Ballow et al. [25] in human lymphocytes, only RAR alpha 2 isoform is upregulated after ATRA treatment, which indicates the presence of functional RARE in the promoter sequence of this gene. Nevertheless, it is worth noting that ATRA increases RAR alpha in rat's Treg cells, which is beneficial for stable expression of FOXP3 and may inhibit undesirable conversion of Treg into Th17 cells [41].

\section{After culturing in the presence of $A T R A, \operatorname{rar} \beta$ and $\operatorname{rxr} \beta$ expression is higher in diseased animals}

On the contrary, we demonstrated varying expression of $\operatorname{rar} \beta$ and $\operatorname{rxr} \beta$ receptor genes in CD4+CD25- cells isolated from healthy animals and those with CIA cultured in vitro in the presence of ATRA. The expression of $\operatorname{rar} \beta$ and $\operatorname{rxr} \beta$ genes was induced under the influence of ATRA in cells isolated from animals with CIA, and was statistically significantly higher $(p<0.01)$ than in CD4+CD25- cells obtained by sorting from lymph nodes and spleen, as well as in comparison to control cultures with no ATRA added.

It has been shown that the expression of $\operatorname{rar} \alpha, \operatorname{rar} \beta$, and $\operatorname{rxr} \beta$ genes in the synovial membrane isolated from humans suffering from osteoarthritis (OA) is variable. Rar $\alpha$ and $\operatorname{rxr} \beta$ expression in humans with $\mathrm{OA}$ is low, whereas the expression of $\operatorname{rar} \beta$ is high [42]. The results of research conducted by Collins-Racie et al. on the expression of $\operatorname{rar} \alpha, \operatorname{rar} \beta$, and $\operatorname{rxr} \beta$ are different from those of our research; we did not observe any differences in $\operatorname{rar} \beta$ expression between CD4+CD25- cells isolated from rats with CIA and those from healthy animals. Our research was conducted with different biological material; CD4+CD25lymphocytes were isolated from lymph nodes and spleen, while Collins-Racie et al. examined gene expression of retinoic acid receptors in the synovial membrane. The presence of the individual retinoic acid receptors correlates with the type of tissue $-\operatorname{rar} \beta$ is present in brain and limb tissues [43], whereas rar $\alpha$ and rary are typical for haematopoietic cells [44]. In CD4+CD25-CD44 ${ }^{\text {lo }} \mathrm{FOXP} 3$ - cells, rar $\alpha$, rar $\beta$, and rary show minimal expression while the expression of rar $\alpha$ is very high [45].

It also seemed that CD4+CD25- cells isolated from rats showed constitutive expression of $\operatorname{rar} \beta$, which is different from the retinoic receptor expression pattern observed in human T lymphocytes, thymocytes and T-cell hybridoma, which constitutively expressed rar- $\alpha$ and rar- $\gamma$ but not rar- $\beta$. On the other hand, for the first time the pres- 
ence of an auto-regulated response element and dependent on ATRA was demonstrated in rar- $\beta$ promoter [46].

Differences in the increase of $\operatorname{rxr} \beta$ gene expression in CD4+CD25- cells after their isolation, sorting, and in vitro culturing in the presence of ATRA may be justified by induction of the aging process of $\mathrm{T}$ lymphocytes in rheumatoid arthritis [47]. Brtko et al. showed that oral supply of $0.5 \mathrm{mg} / \mathrm{kg}$ of body mass of 13-cis retinoic acid in elderly patients suffering from RA induces an increase of $\operatorname{rxr} \beta$ expression in mononuclear cells of peripheral blood [48]. In conclusion, the increase in $\operatorname{rxr} \beta$ gene expression in CD4+CD25- cells may indirectly indicate the acceleration of the aging process of $\mathrm{T}$ lymphocytes during the development of model RA.

It is interesting that in CD4+CD25- cells obtained by sorting from lymph nodes and spleen, no significant differences in the expression of $\operatorname{Rar} \beta$ on protein level was observed between healthy animals and those with CIA, whereas the $\operatorname{Rxr} \beta$ protein was present only in cells isolated from animals with CIA.

It may indicate changes in the cells' metabolism in the course of disease development, which affects the expression management of retinoic acid receptors. Metabolic changes occurring during the progress of the disease concern - among others - inborn errors of metabolism (IEMs), which mainly result from genetic dysfunctions of metabolic signalling pathways [49].

\section{RXRb was not detected in vivo in healthy animals}

In isolated CD4+CD25- cells either from diseased or healthy animals there were no significant differences in the level of transcriptional expression of all examined retinoic acid nuclear receptors. At the protein level it is worth noticing that in healthy animals RXRb was not detected.

So far, little is known about the epigenetic agents that influence the development of RA [50]. Nevertheless, it has been demonstrated that epigenetic agents influence the development and pathophysiology of autoimmune diseases. Especially important are: DNA methylation, histone deacetylation, and the expression of non-coding micro-RNA [51]. Potential hormonal control of gene expression [52] affects the expression of transcript factors, which play an important role in the pathogenesis of autoimmune diseases [53].

In our results it was shown that the expression of retinoic acid receptors in CD4+CD25- cells isolated from healthy rats and rats with CIA on the protein level examined, a statistically significant difference in expression of $\operatorname{Rxr} \beta(p=0.003)$ was demonstrated. In literature, there is no information about the changes in Rxr expression in CIA or RA, but detailed research on osteoarthritis in humans demonstrated numerous essential differences in the expression of transcription factor genes in comparison with healthy human individuals. Reduced expression of $\operatorname{rxr} \beta$ gene in articular cartilage in humans with OA was observed, whereas our research on model RA indicate an increase in $\operatorname{rxr} \beta$ expression, both on the gene and protein level in CD4+CD25- cells isolated from rats with CIA in comparison to those isolated from healthy rats. In our studies the CD4+DC25- cells were cultured under in vitro conditions in the presence of $10 \mathrm{nM}$ ATRA, which is a ligand for the RAR/RXR heterodimers. The differentiation of $\operatorname{rxr} \beta$ expression between RA and OA may occur by different epigenetic mechanisms of these diseases.

All-trans retinoic acid, as a ligand for RAR and RXR transcription factors (retinoic acid receptors), is important not only in gut immunity [54] but also in attenuation of inflammatory conditions in the course of RA development [32]. Rxr proteins are an atypical group of retinoic acid X receptors because they may form heterodimers with other receptors, such as: VDR (vitamin D receptor), LXR (liver $\mathrm{X}$ receptor), or PPARs (peroxisome proliferation-activated receptors) [55].

RXR proteins play a special role in shaping the expression of Foxp3 and the differentiation of CD4+ cells towards Th17 or Treg cells. It has been demonstrated that culturing CD4+ cells in the presence of AM80 and PA024 induces the expression of Foxp3. However, the presence of an antagonist for RAR LE540 eliminates this effect, which indicates that the interaction between RAR and RXR is necessary for the induction of Foxp3 in CD4+ cells [56].

The negative role of the influence of RXR on LRX was indirectly shown on model CIA rheumatoid arthritis in DBA/1 mice, in which an increased pro-inflammatory effect was observed after oral administration of LXR agonists. In human leukocytes in vitro, LXR agonists have induced increased production of pro-inflammatory IL-1 $\beta$, IL-6, and IL-17 cytokines [57]. It was also demonstrated that oral supply of LXR $\alpha$ and LXR $\beta$ (GW3965) agonists in C57BL/6 mice, in which the CIA was triggered, causes the exacerbation of clinical symptoms characteristic of CIA [58]. Thus, the modulation of LXR activity does not seem to be an appropriate target for therapeutic interventions in cases of osteoarthritis.

\section{Summary}

In our work we have demonstrated differential response of naive T CD4+ lymphocytes isolated from rats with CIA and from healthy animals differentiated into Tregs under in vitro conditions in the presence of ATRA. We showed that although ATRA does not increase the frequency of Treg in culture, it significantly increases expression of $\operatorname{rar} \beta$ and $\operatorname{rxr} \beta$ only in lymphocytes taken from diseased animals and foxp3 expression only in healthy animals. Moreover, after ATRA stimulation the frequency of Treg-produced IL-10 tended to be lower in diseased animals than in a healthy group. The results imply that the po- 
tential of naïve cell CD4 lymphocytes to differentiate into Tregs and their putative suppressive function is dependent on the donor's health status.

\section{Executive summary - summary points}

- ATRA did not increase the frequency of Treg in culture; it significantly increased expression of $\operatorname{rar} \beta$ and $\operatorname{rxr} \beta$ only in lymphocytes taken from diseased animals and foxp3 expression only in healthy animals.

- After ATRA stimulation the frequency of Treg-produced IL-10 tended to be lower in diseased animals than in the healthy group. The results imply that the potential of naive cell CD4 lymphocytes to differentiate into Tregs and their putative suppressive function is dependent on the donor's health status.

- Due to the varying immunological potential of CD4+CD25- cells isolated from healthy rats and from those with model RA, one should consider supplementing the screening of patients qualified for immunomodulatory therapies based on the immunosuppressive potential of ATRA-induced iTreg cells.

- Detailed diagnostics of the expression of retinoic acid receptors on gene and protein levels in each patient could increase the effectiveness of immunotherapeutic therapy.

This work was funded and supported by Project UMO-2012/05/N/NZ5/00873 from the National Centre of Science, and was supported by the Wroclaw Centre of Biotechnology program at the Leading National Research Centre (KNOW) from 2014 to 2018.

\section{The authors declare no conflict of interest.}

\section{References}

1. Abbas AK, Benoist C, Bluestone JA, et al. (2013): Regulatory T cells: recommendations to simplify the nomenclature. Nat Immunol 14: 307-308.

2. von Herrath MG, Harrison LC (2003): Antigen-induced regulatory T cells in autoimmunity. Nat Rev Immunol 3: 223-232.

3. Rudensky AY (2011): Regulatory T cells and Foxp3. Immunol Rev 241: 260-268.

4. Sakaguchi S (2011): Regulatory T cells: history and perspective. In: Regulatory T cells. Humana Press 707: 3-17.

5. Clarke N, Germain P, Altucci L, et al. (2004): Retinoids: potential in cancer prevention and therapy. Expert Rev Mol Med 6: 1-23.

6. Niedbala W, Wei XQ, Cai B, et al. (2007): IL-35 is a novel cytokine with therapeutic effects against collagen-induced arthritis through the expansion of regulatory T cells and suppression of Th17 cells. Eur J Immunol 37: 3021-3029.

7. Maynard CL, Hatton RD, Helms WS, et al. (2009): Contrasting roles for all-trans retinoic acid in TGF- $\beta$-mediated induction of Foxp3 and Il10 genes in developing regulatory T cells. J Exp Med 206: 343-357.
8. Cui D, Moldoveanu Z, Stephensen CB (2000): High-level dietary vitamin A enhances T-helper type 2 cytokine production and secretory immunoglobulin A response to influenza A virus infection in BALB/c mice. J Nutr 130: 1132-1139.

9. Min SY, Hwang SY, Park KS, et al. (2004) Induction of IL-10-producing CD4+ CD25+ T cells in animal model of collagen-induced arthritis by oral administration of type II collagen. Arthritis Res Ther 6: R213-R219.

10. Walmsley M, Katsikis PD, Abney E, et al. (1996): Interleukin-10 inhibition of the progression of established collagen-induced arthritis. Arthritis Rheum 39: 495-503.

11. Kochetkova, I, Golden S, Holderness K, et al. (2010): IL-35 stimulation of CD39+ regulatory $\mathrm{T}$ cells confers protection against collagen II-induced arthritis via the production of IL-10. J Immunol 184: 7144-7153.

12. Venken K, Hellings N, Thewissen M, et al. (2008): Compromised CD4+ CD25high regulatory T-cell function in patients with relapsing-remitting multiple sclerosis is correlated with a reduced frequency of FOXP3-positive cells and reduced FOXP3 expression at the single-cell level. Immunology 123: 79-89.

13. Kawashiri SY, Kawakami A, Okada A, et al. (2011): CD4+ CD25highCD127low/- Treg cell frequency from peripheral blood correlates with disease activity in patients with rheumatoid arthritis. J Rheumatol 38: 2517-2521.

14. Peters J, Koenen HJ, Hilbrands LB, et al. (2009): Immunotherapy with regulatory $\mathrm{T}$ cells in transplantation. Immunotherapy 1: 855-857.

15. Morgan ME, Flierman R, van Duivenvoorde LM, et al. (2005): Effective treatment of collagen-induced arthritis by adoptive transfer of CD25+ regulatory T cells. Arthritis Rheum 52: 2212-2221.

16. Kohm AP, Carpentier PA, Anger HA, et al. (2002): Cutting edge: CD4+ CD25+ regulatory T cells suppress antigen-specific autoreactive immune responses and central nervous system inflammation during active experimental autoimmune encephalomyelitis. J Immunol 169: 4712-4716.

17. Mukherjee R, Chaturvedi P, Qin HY, et al. (2003): CD4+ $\mathrm{CD} 25+$ regulatory $\mathrm{T}$ cells generated in response to insulin $\mathrm{B}$ : 9-23 peptide prevent adoptive transfer of diabetes by diabetogenic T cells. J Autoimmun 21: 221-237.

18. Felcenloben I, Piasecki T, Miller J, et al. (2015): Adoptively transferred Tregs accumulate in a site-specific manner and ameliorate signs of less advanced collagen-induced arthritis progress in rats. Immunotheraphy 7: 215-228.

19. Lu L, Ma J, Li Z, et al. (2011): All-trans retinoic acid promotes TGF- $\beta$-induced Tregs via histone modification but not DNA demethylation on Foxp3 gene locus. PLoS One 6: e24590.

20. Scottŕ C, Esposito M, Fazekasova H, et al. (2013): Differential effects of rapamycin and retinoic acid on expansion, stability and suppressive qualities of human CD4+ CD25+ FOXP3+ T regulatory cell subpopulations. Haematologica 98: 1291-1299.

21. Germain P, Chambon P, Eichele G, et al. (2006): International union of pharmacology. LX. Retinoic acid receptors. Pharmacol Rev 58: 712-725.

22. Schenk T, Stengel S, Zelent A (2014): Unlocking the potential of retinoic acid in anticancer therapy. Br J Cancer 111: 20392045.

23. Lanvers C, Hempel G, Blaschke G, et al. (1998): Chemically induced isomerization and differential uptake modulate retinoic acid disposition in HL-60 cells. FASEB J 12: 1627-1633. 
24. Idres N, Marill J, Flexor MA, et al. (2002): Activation of retinoic acid receptor-dependent transcription by all-trans-retinoic acid metabolites and isomers. J Biol Chem 277: 31491-31498.

25. Ballow M, Wang X, Xiang S, et al. (2003): Expression and regulation of nuclear retinoic acid receptors in human lymphoid cells. J Clin Immunol 23: 46-54.

26. Coombes JL, Siddiqui KR, Arancibia-Cárcamo CV, et al. (2007): A functionally specialized population of mucosal CD103+ DCs induces Foxp3+ regulatory T cells via a TGF- $\beta$ and retinoic acid-dependent mechanism. The J Exp Med 204: 1757-1764.

27. Mucida D, Cheroutre H (2007): TGFbeta and retinoic acid intersect in immune-regulation. Cell Adh Migr. 1: 142-144.

28. Sun CM, Hall JA, Blank RB, et al. (2007): Small intestine lamina propria dendritic cells promote de novo generation of Foxp3 T reg cells via retinoic acid. J Exp Med 204: 1775-1785.

29. Hall JA, Cannons JL, Grainger JR, et al. (2011): Essential role for retinoic acid in the promotion of CD4+T Cell effector responses via retinoic acid receptor alpha. Immunity 34: 435-447.

30. Suszko A, Obmińska-Mrukowicz B (2013): Influence of polysaccharide fractions isolated from Caltha palustris $\mathrm{L}$. on the cellular immune response in collagen-induced arthritis (CIA) in mice. A comparison with methotrexate. J Ethnopharmacol 145: 109-117.

31. Benson MJ, Pino-Lagos K, Rosemblatt M, et al. (2007): Alltrans retinoic acid mediates enhanced $\mathrm{T}$ reg cell growth, differentiation, and gut homing in the face of high levels of co-stimulation. J Exp Med 204: 1765-1774.

32. Kwok SK, Park MK, Cho ML, et al. (2012): Retinoic acid attenuates rheumatoid inflammation in mice. J Immunol 189: 1062-1071.

33. Zhou X, Kong N, Wang J, et al. (2010): Cutting edge: alltrans retinoic acid sustains the stability and function of natural regulatory $\mathrm{T}$ cells in an inflammatory milieu. J Immunol 185: 2675-2679.

34. Yang Z, Matteson EL, Goronzy JJ, et al. (2015): T-cell metabolism in autoimmune disease Arthritis Res Ther 17: 29.

35. Straub RH (2014): Insulin resistance, selfish brain, and selfish immune system: an evolutionarily positively selected program used in chronic inflammatory diseases. Arthritis Res Ther 16 (Suppl 2): S4.

36. Michalek RD, Gerriets VA, Jacobs SR, et al. (2011): Cutting edge: distinct glycolytic and lipid oxidative metabolic programs are essential for effector and regulatory CD4+ T cell subsets. J Immunol 186: 3299-3303.

37. Keystone E, Wherry J, Grint P (1998): IL-10 as a therapeutic strategy in the treatment of rheumatoid arthritis. Rheum Dis Clin North Am 24: 629-639.

38. Maynard CL, Hatton RD, Helms WS, et al. (2009): Contrasting roles for all-trans retinoic acid in TGF- $\beta$-mediated induction of Foxp3 and Il10 genes in developing regulatory T cells. J Exp Med 206: 343-357.

39. Adamson PC (1996): All-trans-retinoic acid pharmacology and its impact on the treatment of acute promyelocytic leukemia. Oncologist 1: 305-314.

40. Takeyama K, Kojima R, Ohashi T, et al. (1996): Retinoic acid differentially up-regulates the gene expression of retinoic acid receptor alpha and gamma isoforms in embryo and adult rats. Biochem Biophys Res Commun 222: 395-400.

41. Brown CC, Esterhazy D, Sarde AA, et al. (2015): Retinoic acid is essential for Th1 cell lineage stability and prevents transition to a Th17 cell program. Immunity 42: 499-511.

42. Collins-Racie LA, Yang Z, Arai M, et al. (2009): Global analysis of nuclear receptor expression and dysregulation in human osteo- arthritic articular cartilage: reduced LXR signaling contributes to catabolic metabolism typical of osteoarthritis. Osteoarthritis Cartilage 17: 832-842.

43. Ghyselinck NB, Dupé V, Dierich A, et al. (1997): Role of the retinoic acid receptor beta (RAR $\beta$ ) during mouse development. Int J Dev Biol 41: 425-447.

44. Dzhagalov I, Chambon P, He YW (2007): Regulation of CD8+ T lymphocyte effector function and macrophage inflammatory cytokine production by retinoic acid receptor gamma. J Immunol 178: 2113-2121.

45. Hall JA, Cannons JL, Grainger JR, et al. (2011): Essential role for retinoic acid in the promotion of CD4(+) T cell effector responsesvia retinoic acid receptor alpha. Immunity 34: 435-447.

46. Sucov H, Murakami K, Evans R (1990): Characterization of an autoregulated response element in the mouse retinoic acid receptor type f8 gene (vitamin A/steroid receptor/transcription). Proc Natl Acad Sci U S A 87: 5392-5396.

47. Weyand CM, Yang Z, Goronzy JJ (2014): T cell aging in rheumatoid arthritis. Curr Opin Rheumatol 26: 93-100.

48. Brtko J, Rock E, Nezbedova P, et al. (2007): Age-related change in the retinoid $\mathrm{X}$ receptor beta gene expression in peripheral blood mononuclear cells of healthy volunteers: effect of 13-cis retinoic acid supplementation. Mech Ageing Dev 128: 594-600.

49. Childs B, Valle D, Jimenez-Sanchez G (2001): The Inborn Error and Biochemical Individuality. In: The Metabolic \& Molecular Bases of Inherited Disease. Sciver CS, Beaudet AL, Sly WS, Valle D (eds.). McGraw-Hill, New York 155-166.

50. Glant TT, Mikecz K, Rauch TA (2014): Epigenetics in the pathogenesis of rheumatoid arthritis. BMC Med 12: 35.

51. Lu Q (2013): The critical importance of epigenetics in autoimmunity. J Autoimmun 41: 1-5.

52. Pike JW, Meyer MB, John HC, et al. (2015): Epigenetic histone modifications and master regulators as determinants of context dependent nuclear receptor activity in bone cells. Bone 81: 757764.

53. Sun SC, Chang JH, Jin J (2013): Regulation of nuclear factor- $\kappa B$ in autoimmunity. Trends Immunol 34: 282-289.

54. Benson M, Pino-Lagos K, Rosemblatt M, et al. (2007): All-trans retinoic acid mediates enhanced $\mathrm{T}$ reg cell growth, differentiation, and gut homing in the face of high levels of co-stimulation. J Exp Med 204: 1765-1774.

55. Kagechika H, Shudo K (2005): Synthetic retinoids: recent developments concerning structure and clinical utility. J Med Chem 48: 5875-5883.

56. Takeuchi H, Yokota-Nakatsuma A, Ohoka Y, et al. (2013): Retinoid $\mathrm{X}$ receptor agonists modulate Foxp3+ regulatory T cell and Th17 cell differentiation with differential dependence on retinoic acid receptor activation. J Immunol 191: 3725-3733.

57. Asquith DL, Miller AM, Hueber AJ, et al. (2009): Liver X receptor agonism promotes articular inflammation in murine collagen-induced arthritis. Arthritis Rheum 60: 2655-2665.

58. Asquith DL, Miller AM, Reilly J, et al. (2011): Simultaneous activation of the liver $\mathrm{X}$ receptors (LXR $\alpha$ and LXR $\beta$ ) drives murine collagen-induced arthritis disease pathology. Ann Rheum Dis 70: 2225-2228.

59. Benson MJ, Pino-Lagos K, Rosemblatt M, et al. (2007): All-trans retinoic acid mediates enhanced $\mathrm{T}$ reg cell growth, differentiation, and gut homing in the face of high levels of co-stimulation. J Exp Med 204: 1765-1774. 